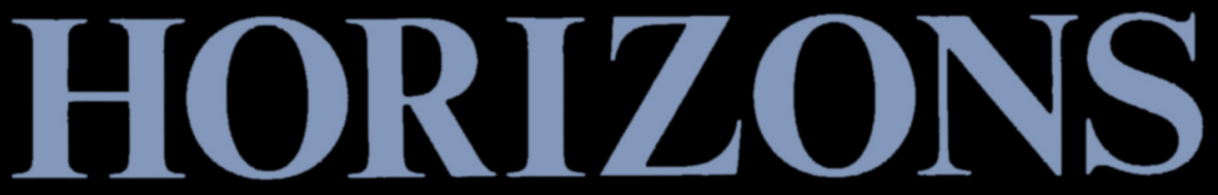

Volume 26

Spring, 1999

Number 1

ARTICLES

Michael G. Lawler and Covenant Generativity: Toward a Theology of Gail S. Risch Christian Family

Keith Soko, Human Rights and the Poor in the World Religions Don Schweitzer, Gregory Baum's Theory of Social Change

Marie L. Baird, Emmanuel Levinas and the Problem of Meaningless Suffering: The Holocaust as a Test Case

\title{
CREATIVE TEACHING
}

Mary E. Hobgood, Mentoring Moral Courage: Resources in Liberation Ethics, Community Services, and the Social Commitment of the Academy

\section{EDITORIAL ESSAY}

Stephen J. Duffy, A Theology of the Religions and/or A Comparative Theology?

\section{REVIEW SYMPOSIUM}

Elizabeth A. Johnson's Friends of God and Prophets: A Feminist Theological Reading of the Communion of Saints Four Perspectives: Michael Downey, Lillian Bozak-De Leo, Robert A. Krieg, Jeanette Rodriguez

Author's Response: Elizabeth A. Johnson

Plus Reviews of 30 Books 


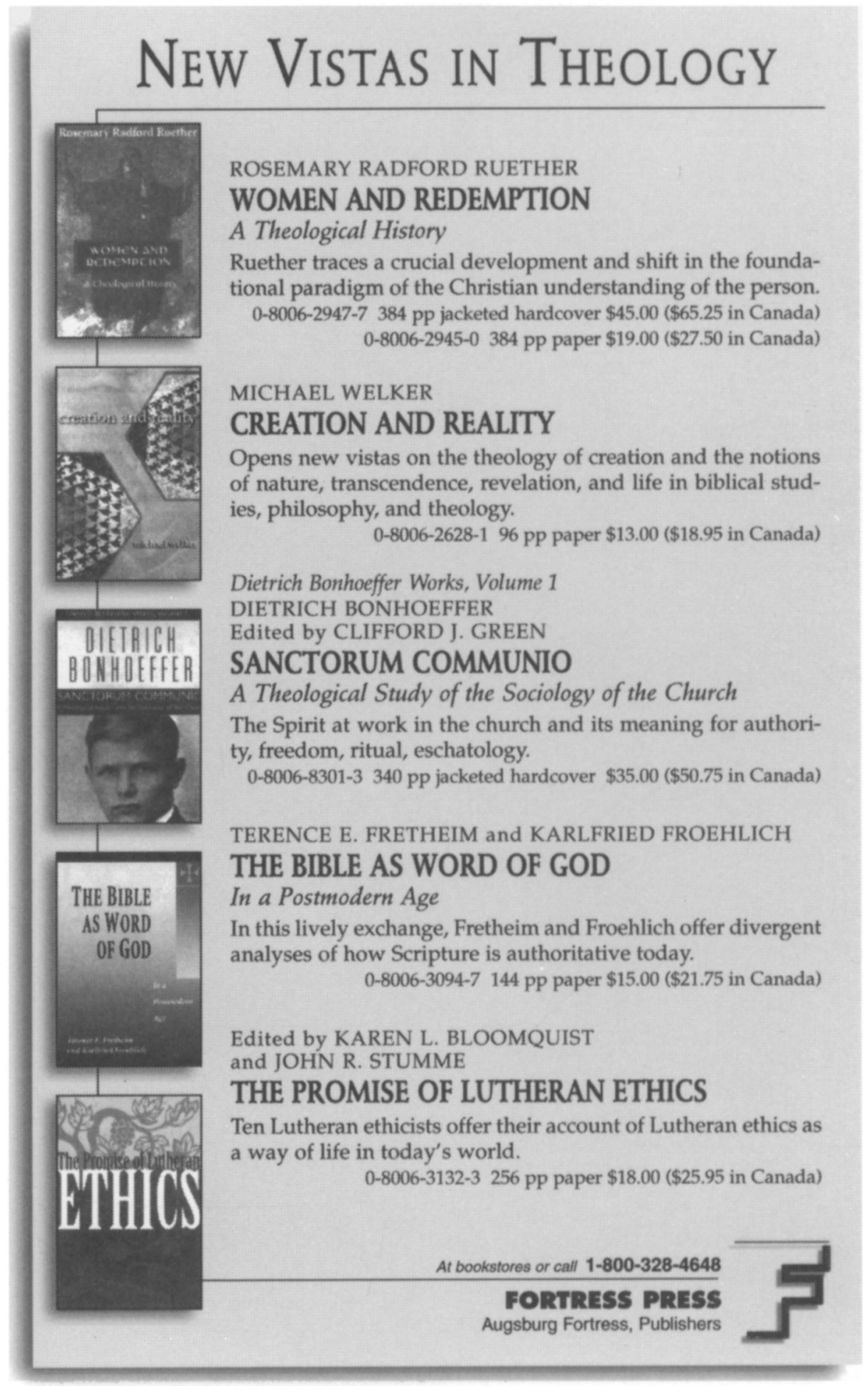




\title{
HORIZONS
}

\section{The Journal of the College Theology Society}

\author{
Published at Villanova University
}

Volume 26

Spring, 1999

Number 1

\section{ARTICLES}

Covenant Generativity: Toward a Theology

Michael G. Lawler of Christian Family and Gail S. Risch

Human Rights and the Poor in

the World Religions

Keith Soko

Don Schweitzer $\mathbf{5 4}$

Gregory Baum's Theory of Social Change

Emmanuel Levinas and the Problem

of Meaningless Suffering: The

Holocaust as a Test Case

Marie L. Baird

\section{CREATIVE TEACHING}

Mentoring Moral Courage: Resources in

Liberation Ethics, Community Service, and

the Social Commitment of the Academy

Mary E. Hobgood

85

\section{EDITORIAL ESSAY}

A Theology of the Religions and/or

A Comparative Theology?

Stephen J. Duffy 105

\section{REVIEW SYMPOSIUM}

Elizabeth A. Johnson's Friends of God and Prophets: A Feminist

Theological Reading of the Communion of Saints

Four Perspectives Michael Downey 116

Lillian Bozak-De Leo 119

Robert A. Krieg 122

Jeanette Rodriguez 125

Author's Response Elizabeth A. Johnson

\section{BOOK REVIEWS}

James D. G. Dunn, The Theology of

Paul the Apostle Pheme Perkins 136

Robert Ellsberg, All Saints: Daily

Reflections on Saints, Prophets,

and Witnesses for Our Time John H. Wright, S.J. 137

John Comenius, John Comenius: The Labyrinth

of the World and the Paradise of the Heart Daniel DiDomizio 139 
Sisters, Servants of the Immaculate Heart of Mary,

Building Sisterhood: A Feminist History of

the Sisters, Servants of the Immaculate

Heart of Mary

Sandra Yocum Mize

140

Christopher Vecsey, The Paths of Kateri's Kin Leonard J. Biallas 142

Robert A. Krieg, C.S.C., Roman Guardini:

A Precursor of Vatican II Stephen J. Duffy 143

Edmond J. Dunn, What Is Theology?

Foundational and Moral Edward J. Peck 145

Robert Cummings Neville, A Theology Primer Lewis S. Ford 146

Kenan B. Osborne, O.F.M., The Resurrection

of Jesus: New Considerations for Its

Theological Interpretation James J. Buckley 148

Robert S. Pelton, C.S.C., ed., Small Christian

Communities: Imagining Future Church

Gary MacEoin, ed., The Papacy and

the People of God

Dennis M. Doyle 149

William Cenkner, ed., The Multicultural

Church: A New Landscape

in U.S. Theologies

Billi Salisbury Baladouni 151

Michael G. Lawler, Symbol and Sacrament:

A Contemporary Sacramental Theology

Brennan R. Hill 152

Gregory L. Klein, O.Carm. and Robert A. Wolfe,

O.Carm., Pastoral Foundations of the

Sacraments: A Catholic Perspective

Francis J. Buckley, S.J. 153

Rosemary Luling Haughton, Images for Change:

The Transformation of Society Eilish Ryan, C.C.V.I. 154

Edward T. Oakes, Pattern of Redemption:

The Theology of Hans Urs von Balthasar

Paul Descouvemont, Thérèse of Lisieux and

Marie of the Trinity; Conrad de Meester, ed.,

Saint Thérèse of Lisieux: Her Life, Times, and

Teaching; and Jean-François Six, Light of the

Night: The Last Eighteen Months in

the Life of Thérèse of Lisieux

Joann Wolski Conn 157

Russell B. Connors, Jr. and Patrick T. McCormick,

Character, Choices \& Community: The

Three Faces of Christian Ethics Walter E. Conn 160

Daniel C. Maguire and Larry L. Rasmussen,

Ethics for a Small Planet: New Horizons on

Population, Consumption, and Ecology William J. Colllinge 155

Eileen P. Flynn, Issues in Medical Ethics

Pamela A. Smith 161

James J. Megivern, The Death Penalty: An

Historical and Theological Survey Patricia Beattie Jung 162 Joseph E. Capizzi 
Reinhard Hutter and Theodor Dieter, eds.,

Ecumenical Ventures in Ethics:

Protestants Engage Pope John

Paul II's Moral Encyclicals

Charles E. Curran 164

Dennis Janz, World Christianity and Marxism

Stephen J. Casey 165

Thomas E. Baker and Timothy W. Floyd, eds.,

Can a Good Christian Be a Good Lawyer?

Homilies, Witnesses, and Reflections

Anthony Battaglia 166

Mary C. Boys, Jewish-Christian Dialogue:

One Woman's Experience

Fayette Breaux Veverka 168

Gerhart B. Ladner, God, Cosmos, and Human-

kind: The World of Early Christian

Symbolism; and Jeffrey F. Hamburger,

Nuns as Artists: The Visual

Culture of a Medieval Convent

Douglas Burton-Christie 170

Robert J. Hater, The Search for Meaning:

Myth and Mystery in the New Millennium .... Francis Dorff, O.Praem. 172

BOOKS RECEIVED

Copyright $(1999$ College Theology Society

Printed in the United States of America 


\section{HORIZONS}

\section{The Journal of the College Theology Society}

Horizons, The Journal of the College Theology Society is published biannually in Spring and Fall at Villanova University, Villanova, PA 19085.

Yearly subscription: individual $\$ 16.00$, institutional $\$ 40.00$. Send remittance, payable to Wilfrid Laurier University Press, to Wilfrid Laurier University Press, Wilfrid Laurier University, Waterloo, Ontario, Canada N2L 3C5. Changes of address should also be sent to this address. Horizons is automatically received through membership in the College Theology Society.

Manuscripts, editorial and business correspondence, book reviews, advertising copy, and orders for single issues (individual $\$ 8.00$, institutional $\$ 20.00$ ) should be addressed to The Editor, Horizons, Journal of the CTS, Villanova University, Villanova, PA 19085. Telephone: (610) 519-7302. E-mail: HORIZONS@EMAIL.VILL.EDU

In submitting manuscripts, please send four clear copies. Author's name should appear only on an unpaginated cover sheet, with address and essay's title. No other identifying reference to author should appear on the manuscript. All references to author's work in text or notes should be in the third person. Essay's title should appear at top of first page of text. Notes should be placed on separate sheets at end. Full double spacing should be used throughout, including indented quotations and notes. Top, bottom, and right-hand margins should be at least one inch; left-hand margins at least one-and-a-half. Manuscripts should be accompanied by an abstract of one hundred fifty words or less and an author vita of one hundred words or less. Authors should state that the manuscript will not be submitted to another journal until Horizons' evaluation is completed. Manuscripts will be returned if postage is supplied.

Articles appearing in Horizons are abstracted and indexed in: The Catholic Periodical and Literature Index; Guide to Social Science and Religion in Periodical Literature; Index to Religious Periodical Literature; New Testament Abstracts; Religious and Theological Abstracts; and Social Science Citation Index. Articles are indexed in Religion Index One: Periodicals; book reviews indexed in Index to Book Reviews in Religion. Horizons is available in microform from University Microfilms International, 300 North Zeeb Road, Department P.R., Ann Arbor, MI 48106.

\section{(ङ) COLLEGE THEOLOGY SOCIETY}

The College Theology Society is a professional organization of college and university professors of religion in the United States and Canada.

The purpose of the College Theology Society is to improve the quality of the teaching of religion: by stimulating and sharing scholarly research; by developing programs of theology and religious studies which meet student needs and interests; and by exploring, evaluating, and encouraging effective ways of teaching which are interdisciplinary and ecumenical.

Annual membership dues in the Society are $\$ 40.00$ (Full Professional or Associate), $\$ 45.00$ (Joint Professional for husband and wife), and \$20.00 (Graduate Student). Membership in the Society includes a subscription to Horizons. Contact Alexis Doval, St. Mary's College, Box 5150, Moraga, CA 94575. Telephone: (925) 631-4403. E-mail: adoval@stmarys-ca.edu 


\section{EDITOR}

Walter E. Conn

Villanova University

\section{ASSOCIATE EDITORS}

Lisa Sowle Cahill

Boston College

Denise Lardner Carmody

Santa Clara University

Anne Carr

The University of Chicago

Bernard Cooke

College of the Holy Cross

Lawrence S. Cunningham

University of Notre Dame

Charles E. Curran

Southern Methodist University

Margaret A. Farley

Yale Divinity School

Elisabeth Schüssler Fiorenza

Harvard Divinity School

Francis Schüssler Fiorenza

Harvard Divinity School
Mary Ann Hinsdale College of the Holy Cross

Elizabeth A. Johnson Fordham University

Paul F. Knitter Xavier University

Pheme Perkins Boston College

Sandra M. Schneiders, I.H.M. Jesuit School of Theology at Berkeley

William M. Shea Saint Louis University

Gerard S. Sloyan

The Catholic University of America

William M. Thompson

Duquesne University

David W. Tracy

University of Chicago

Mary Jo Weaver

Indiana University

BOOK REVIEW EDITOR

Joann Wolski Conn

Neumann College

BUSINESS EDITOR

Anne McGuire

Haverford College

EDITORIAL ASSISTANT

Irene C. Noble 


\section{HORIZONS}

\section{The Journal of the College Theology Society}

A journal exploring developments in Catholic theology, the total Christian tradition, human religious experience, and the concerns of creative teaching from the college and university environment.

Christian family, the poor, social change, suffering-here we have theology directly addressed to the concrete realities of human living. First, Michael Lawler and Gail Risch reflect theologically on the Christian family in "Covenant Generativity," and Keith Soko surveys "Human Rights and the Poor in the World Religions." Then, Don Schweitzer looks at social change in Gregory Baum's thought, and Marie Baird uses the Holocaust as a test case for her reflection on "Emmanual Levinas and the Problem of Meaningless Suffering."

Many of these themes are picked up in the Creative Teaching section by Mary Hobgood as she considers liberation ethics, community service, and the academy's social commitment as resources for "Mentoring Moral Courage."

The scene changes as we move to the Editorial Essay section, where Stephen Duffy reflects on a recent debate in his "A Theology of the Religions and/or a Comparative Theology?"

Our Review Symposium features Elizabeth Johnson's feminist theological reflections on the Communion of Saints: Friends of God and Prophets. The author responds to essays by Michael Downey, Lillian Bozak-DeLeo, Robert Krieg, and Jeanette Rodriguez. Reviews of thirty recent books bring the issue to a close.

-Walter E. Conn 